\title{
EFFECT OF CRUSHED GLASS AGGREGATES ON THE PHYSICO-MECHANICAL PROPERTIES OF MICRO-CONCRETE
}

\author{
Maza Mekki, Naceri Abdelghani and Zitouni Salim \\ Geo-Materials Development Laboratory, Technology Faculty, Civil Engineering \\ Department, M'sila University, Algeria. \\ mekkimaza3@gmail.com
}

\begin{abstract}
Maza Mekki, Naceri Abdelghani and Zitouni Salim. 2018. Effect of crushed glass aggregates on the physico-mechanical properties of micro-concrete. Lebanese Science Journal, 19(2): 210-228.

Demand for aggregates is growing considerably in line with the development of construction in Algeria. To overcome it, it will be necessary to ensure a rational exploitation of the aggregates available to the country by aevaluation of the existing resources. According to the statistics, the glass wastes accounted for $7 \%$ of the world's solid wastes. The glass wastes can be used in concrete production in two forms: replacing part of aggregate or using as supplementary cement material to replace cement. Using glass wastes to produce recycled aggregates for the production of new concrete reduces the consumption of natural resources as well as landfills. This work consists in formulating a micro-concrete with a substitution of 5 to $25 \%$ by weight of crushed calcareous aggregates of fraction 3/8 by glass aggregates of the same fraction 3/8. The incorporation of glass wastes as an aggregate in the micro-concrete plays a role of skeleton and improves its compressive mechanical strength. The compressive strength is considerably improved by substitution of crushed calcareous aggregates by recycled glass aggregates. The optimum has been reached for a value of around 46 MPa for a substitution of $10 \%$ of crushed limestone aggregates. The substitution of $10 \%$ crushed gravel by crushed glass allows improving the strength of more than 27\%. The results obtained proved that waste glass can be used as an aggregate for producing micro-concrete with a relatively high strength which will not deteriorate with time.
\end{abstract}

Keywords: waste glass, crushed aggregates, micro-concrete, physical and mechanical properties. 


\section{INTRODUCTION}

The universal need to protect the environment and to properly manage resources requires the establishment of new laws and the adaptation of new concepts (Shayan and $\mathrm{Xu}, 2004)$. Waste recovery and recycling is an effective means of meeting the economic and environmental constraints of recent years (Jin et al.,2000; Girbes et al., 2004). Waste is a real problem, inevitable to all biological life and industrial activity (Seung Bum et al.,2004; Chen et al., 2006). Waste glass is a major component of the solid waste stream in many countries. Recycling and recovery of waste are now considered as a solution for the future in order to meet the shortfall between production and consumption and to protect the environment (Liang et al., 2007; Shao et al. 2000).

The last decade has seen enormous research in the field of civil engineering all over the world to study the effect of several additions of various natures on the rheological and mechanical characteristics of concrete and mortar. In order to provide solutions to improve the characteristics of concrete and mortar and to contribute to the fight against pollution and the preservation of nature and reduce energy bills, recycling of several materials seemed necessary. Thus, recycling glass from several forms (bottles, windscreens, flat glass, etc.) in concrete could be an attractive ecological and economic alternative, allowing the elimination of bulky and polluting discharges since its qualifies as a new source of building materials (Serniabat et al., 2004).

Glass has been an indispensable material to man for several properties such as the ability to take different shapes easily, surface clarity, abrasion resistance, safety and durability. As the demand and use of glass increases, also did the glass waste. The United Nations estimate of 200 million tons of solid waste annually, 70\% of which is glass.Glass is a multi-life material and can be recycled several times. However, it is necessary for the glass from the selective collection to be separated beforehand according to color to be converted into cullet for use again in the manufactureof glass packages (Dragica et al., 2012; Gunalaan; and Seri Ganis Kanapathy, 2013).

The use of glass waste as aggregates in concrete has great potential for future high quality concrete development. Glass wastecan be used in concrete production in two forms: replacing part of aggregate or using as supplementary cementitious material to replace some cement. According to statistics, waste glass accounted for $7 \%$ of the world's solid waste. Using crushed glass waste concrete to produce coarse aggregate for the production of new concrete reduces the consumption of natural resources as well as landfills.

Crushed glass wastes are used as aggregates for making concrete, their properties are comparable to those of other aggregates that provide, strength and 
durability (Zhang and Zhao, 2011; Limbachiya et al., 2012). Studies have shown that the use of glass in concrete seems to be a promising avenue for massive retraining (Liu et al., 2015).

The utilization of waste materials (slag, fly ash, glass, plastic, etc...) in concrete manufacturing is significant due to its engineering, financial, environmental and ecological benefits. Most of the time, the collected glass is a mixed product and reuse may become difficult. Moreover, unlike other waste, glass is imperishable and therefore harmful to the environment. Several alternatives exist reuse glass, it is used for other applications (road abrasive, glass wool, municipal filtration etc ...) or stored in landfills. According to some existing studies these uncorked, which requires a preconditioning (including grinding), have limited development and fail to absorb the amount of glass recovered (Liu et al., 2016; Topc and Canbaz, 2004).

It is worth to mention in this context that research work found in the litterature about the specific reuse of recycled glass aggregates replacement in micro-concrete are limited. These still concerned much more with their incorporation in concrete formulation.

This experimental study investigated the effect of recycled glass aggregate on the fresh and hardened characteristics of micro-concrete. The recycled crushed glass aggregate added to the cementitious matrix plays a skeleton role and improves its mechanical strength.

In order to provide a lasting solution to the problem of glass reuse, another encouraging track is to use it to enhance concrete and micro-concrete. By undergoing a slight crushing, glass can be used as aggregate in concrete. This treatment has the advantage of low cost.

The main objective of this study is to demonstrate the possibility of adding glass waste in the micro concrete and take advantage of its hydrophobic nature which reduces the amount of added water which leads to a reduction of the w/c and thus direct improvement of the micro-concrete compressive strength. This work analyzed the mechanical properties in the fresh and hardened state of the micro concrete with a substitution rate of limestone gravel by glass debris varying between 0 to $25 \%$. The results of these tests were compared with those of a micro -concrete control. 


\section{MATERIALS AND METHODS}

The objective of this study is to investigate the effect of reuse recycled glass aggregates waste at various rates $(0 \%, 5 \%, 10 \%, 15 \%, 20 \%$ and $25 \%)$ as partial replacement of natural aggregates (crushed gravel) on micro-concrete properties such as workability, density, water cement ratio and the compressive strength. Thus, to determine the optimum rate of crushed glass aggregates which can give maximum mechanical strength.

\section{Materials used}

The micro-concrete mixtures were prepared at the laboratory of the Civil Engineering Department, M'sila University (Algeria), using the following materials:

(i) Natural Aggregates (gravel and sand) - were obtained by grinding rock from a Cosider quarry in the EL-Euch region (BordjBouArreridj) in Algeria.The size of particlesin the crushed aggregates used ranged from $0.08 \mathrm{~mm}$ to $8 \mathrm{~mm}$. The main physical characteristics of the aggregates are summarized in Table 1.The mineralogical composition (mineral phases) of the crushed sand was investigated by the X-ray diffraction (XRD) using a diffractometer. The crystalline mineral phases identified for the crushed sand (Figure 1) is mainly composed of quartz $\left(\mathrm{SiO}_{2}\right)$; and calcite $\left(\mathrm{CaCO}_{3}\right)$. It has a small but evident band ranging from $20^{\circ}$ and $30^{\circ}$, indicating the presence of amorphous materials. Silicate and lime are predominant in terms of chemical composition suggesting the presence of alumina, iron and magnesia in small quantities. The main mechanical characteristics and chemical analysis of these fractions are combined in Tables 1 and 2, respectively. The sieve analysis was obtained according to AFNOR standard NE EN 933-1.

Table 1. Physical properties of manufactured fine and coarse aggregates (crushed gravel, crushed glass and crushed sand).

\begin{tabular}{|l|c|c|c|c|c|c|c|}
\hline $\begin{array}{l}\text { Type of } \\
\text { material }\end{array}$ & $\begin{array}{l}\text { Absolute } \\
\text { Density } \\
(\mathrm{kg} / \mathrm{l})\end{array}$ & $\begin{array}{l}\text { Bulk } \\
\text { Density } \\
(\mathrm{kg} / \mathrm{l})\end{array}$ & $\begin{array}{l}\text { Compactness } \\
(\%)\end{array}$ & $\begin{array}{l}\text { Porosity } \\
(\%)\end{array}$ & $\begin{array}{l}\text { Abrasion } \\
\text { resistance } \\
(\mathrm{L} . \mathrm{A})\end{array}$ & $\begin{array}{l}\text { Water } \\
\text { absorption } \\
(\%)\end{array}$ & $\begin{array}{l}\text { Fineness } \\
\text { modulus }\end{array}$ \\
\hline $\begin{array}{l}\text { Crushed } \\
\text { gravel }(3 / 8)\end{array}$ & 2,54 & 1,25 & 49,17 & 50,23 & 27,875 & 2,35 & ----- \\
\hline $\begin{array}{l}\text { Crushed } \\
\text { glass }(3 / 8)\end{array}$ & 2,43 & 1,33 & 54,50 & 45,50 & ----- & ----- & ----- \\
\hline $\begin{array}{l}\text { Crushed sand } \\
(0 / 5)\end{array}$ & 2,55 & 1,48 & 63,37 & 36,63 & ---- & 3,84 & 2,92 \\
\hline
\end{tabular}


Table 2. Chemical analysis of crushed gravel, crushed glass and crushed sand studied.

\begin{tabular}{|l|c|c|c|c|c|c|c|c|}
\hline \multirow{2}{*}{$\begin{array}{l}\text { Type of } \\
\text { Material }\end{array}$} & \multicolumn{7}{|c|}{ Elements and contents (\%) } \\
\cline { 2 - 9 } & $\mathrm{SiO}_{2}$ & $\mathrm{AL}_{2} \mathrm{O}_{3}$ & $\mathrm{CAO}$ & $\mathrm{Fe}_{2} \mathrm{O}_{3}$ & $\mathrm{MgO}$ & $\mathrm{K}_{2} \mathrm{O}$ & $\mathrm{Na}_{2} \mathrm{O}$ & $\mathrm{SO}_{3}$ \\
\hline $\begin{array}{l}\text { Crushed } \\
\text { Gravel (3/8) }\end{array}$ & 36,66 & 1,30 & 34,16 & 0,98 & 2,83 & 0,20 & 00,05 & ---- \\
\hline $\begin{array}{l}\text { Crushed Glass } \\
(3 / 8)\end{array}$ & 73,00 & 1,50 & 09,30 & ----- & 3,00 & 0,30 & 13,00 & ---- \\
\hline $\begin{array}{l}\text { Crushed Sand } \\
(0 / 5)\end{array}$ & 40,65 & 8,87 & 40,56 & 3,25 & 0,79 & 0,65 & 00,01 & ---- \\
\hline
\end{tabular}

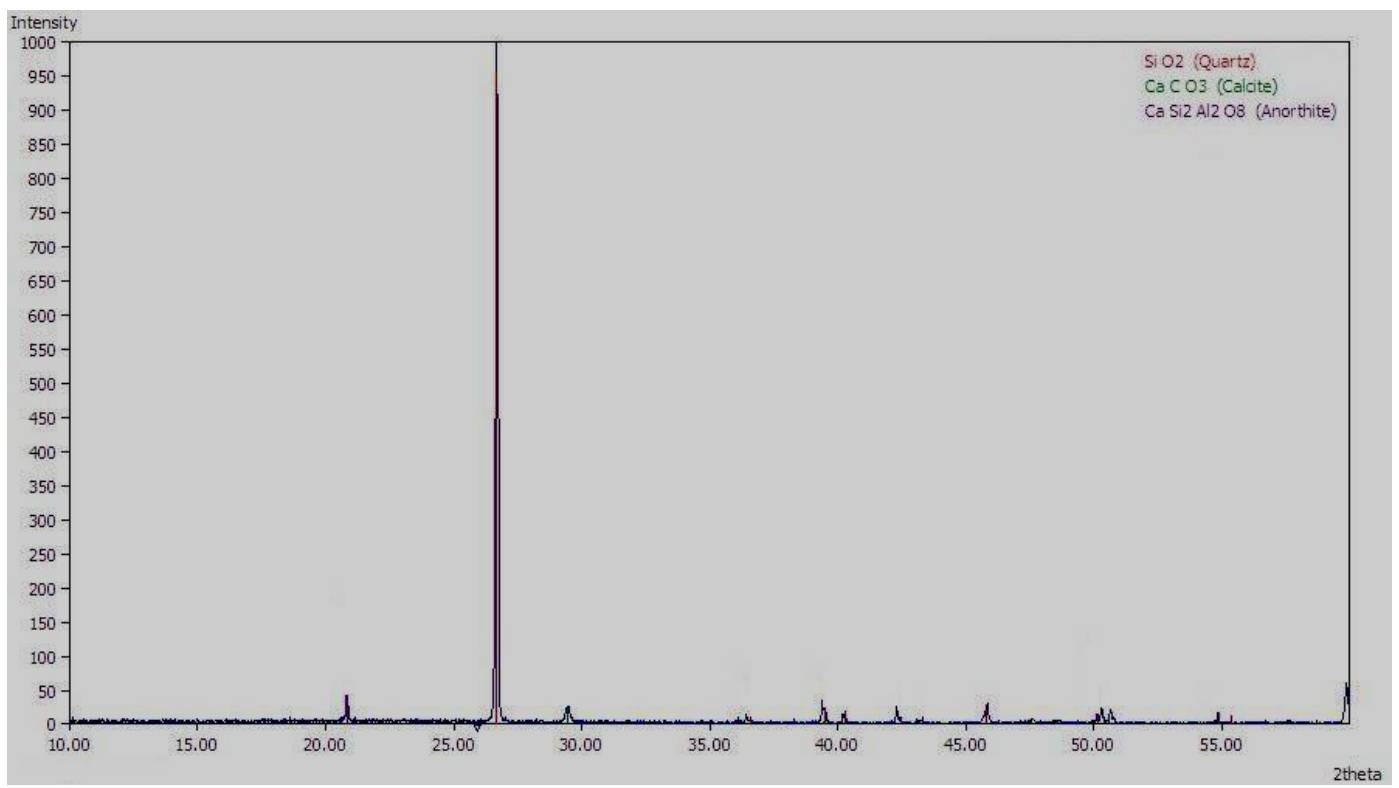

Figure 1. X-ray diffraction (XRD) analysis of crushed sand.

(ii) Crushed glass aggregates (waste glass) - was obtained by a slight crushing of glasspieces of various origins (bottles, by car breeze, plates, etc.). Sieve analysis was obtained according to AFNOR standard NE EN 933-1.Crushed gravel particles were substitutedwith differents rates of crushed glass $(5,10,15,20,25)$. The main physical properties and chemical compositions of crushed glass are summarized in Tables 1 and 2. The particle size distribution curveof crushed gravel, crushed glass and sand studiedis shown in Figures 2 and 3. The sample of natural aggregates (calcareous crushed gravels) and artificial aggregates (waste crushed glass) utilized in this study are shown in Figures 4 and 5. 


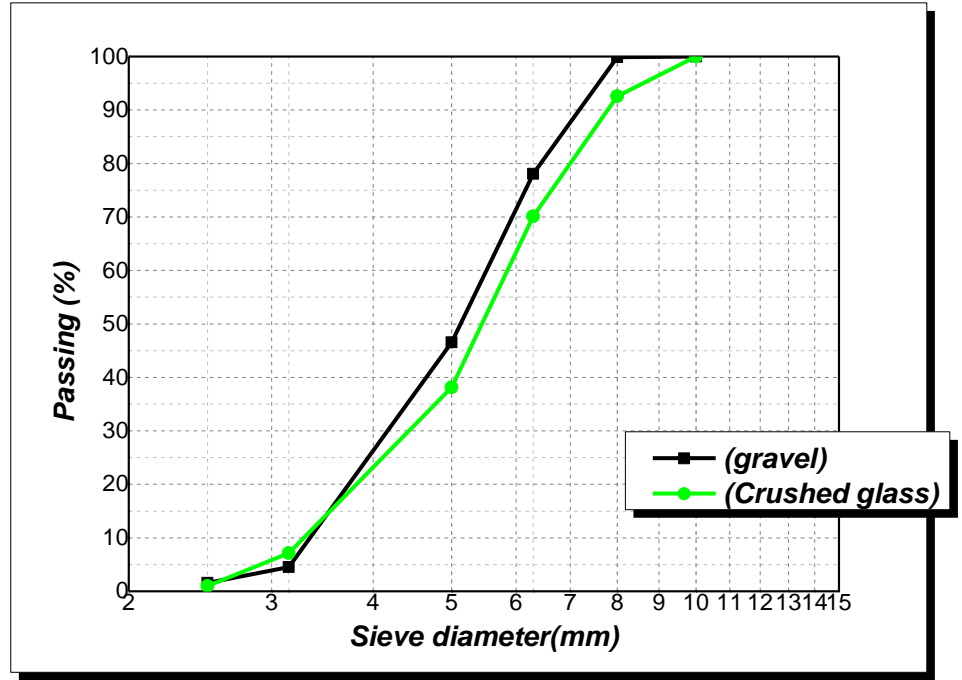

Figure 2. Particle size distribution curve of the crushed gravel and crushed glass used.

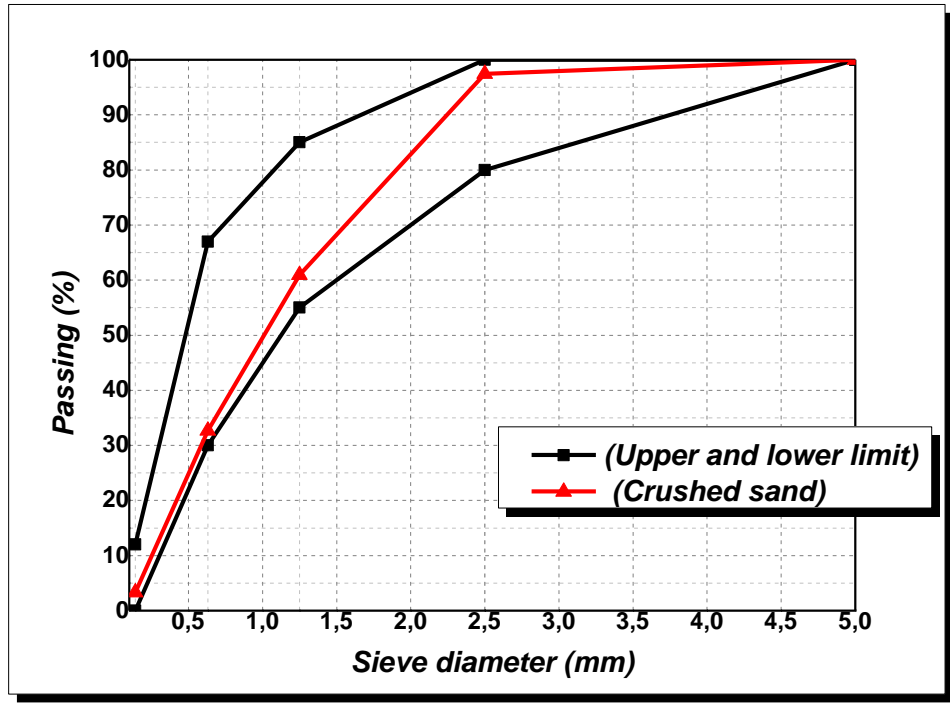

Figure 3. Particle size distribution curve of the crushed sand used. 


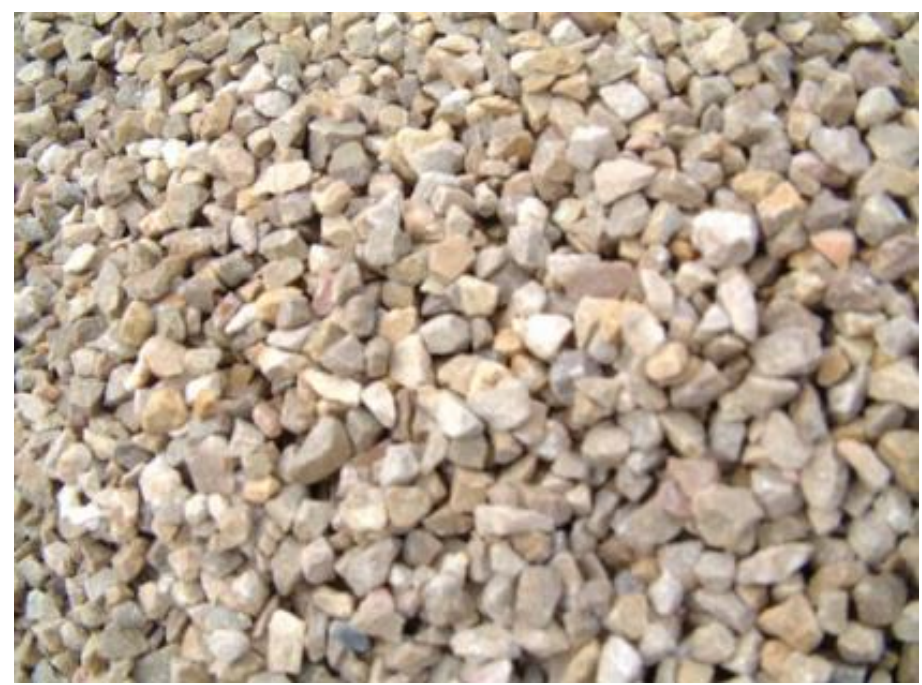

Figure 4. Sample of natural crushed gravel.

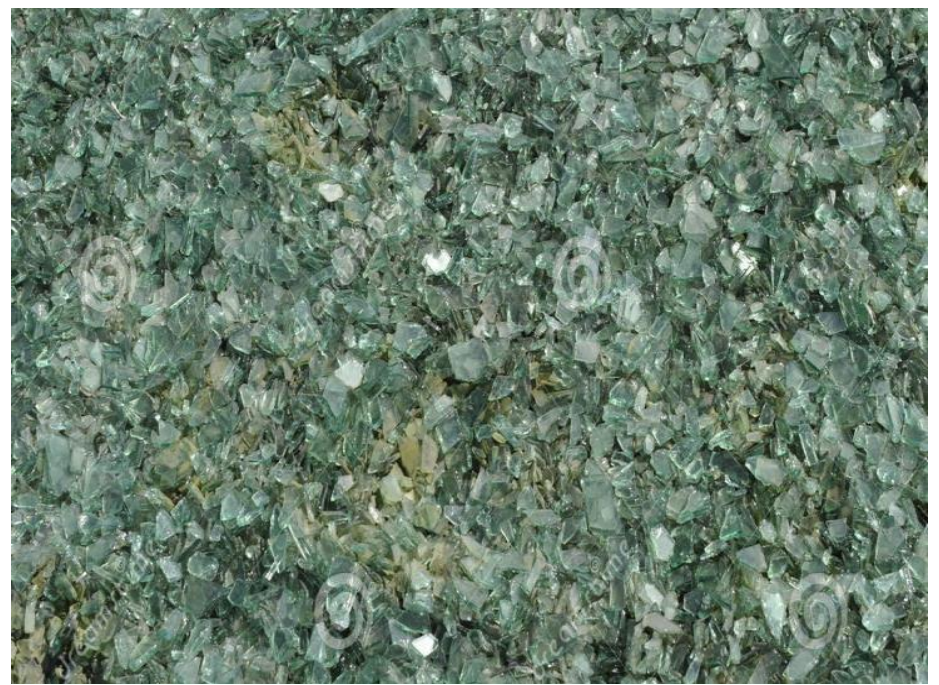

Figure 5. Sample of crushed glass waste.

(iii) Cements- the Portland cement type CEM II/A 42.5 from Hammam Dalâa local factory was used. The absolute density, bulk density and porosity were $3.1 \mathrm{~g} / \mathrm{cm}^{3}, 1.9$ $\mathrm{g} / \mathrm{cm}^{3}$ and $41.93 \%$, respectively. The Blaine specific surface area (fineness) was 3800 $\mathrm{cm}^{2} / \mathrm{g}$. The fineness (specific surface area) of the cement studied was determined by air permeability apparatus and the chemical composition wasdetermined by X-ray fluorescence spectrometry (XRF). Chemical and mineralogical compositions of the cement used are shown in Table 3. The DRX analysis is shown in Figure 6. 


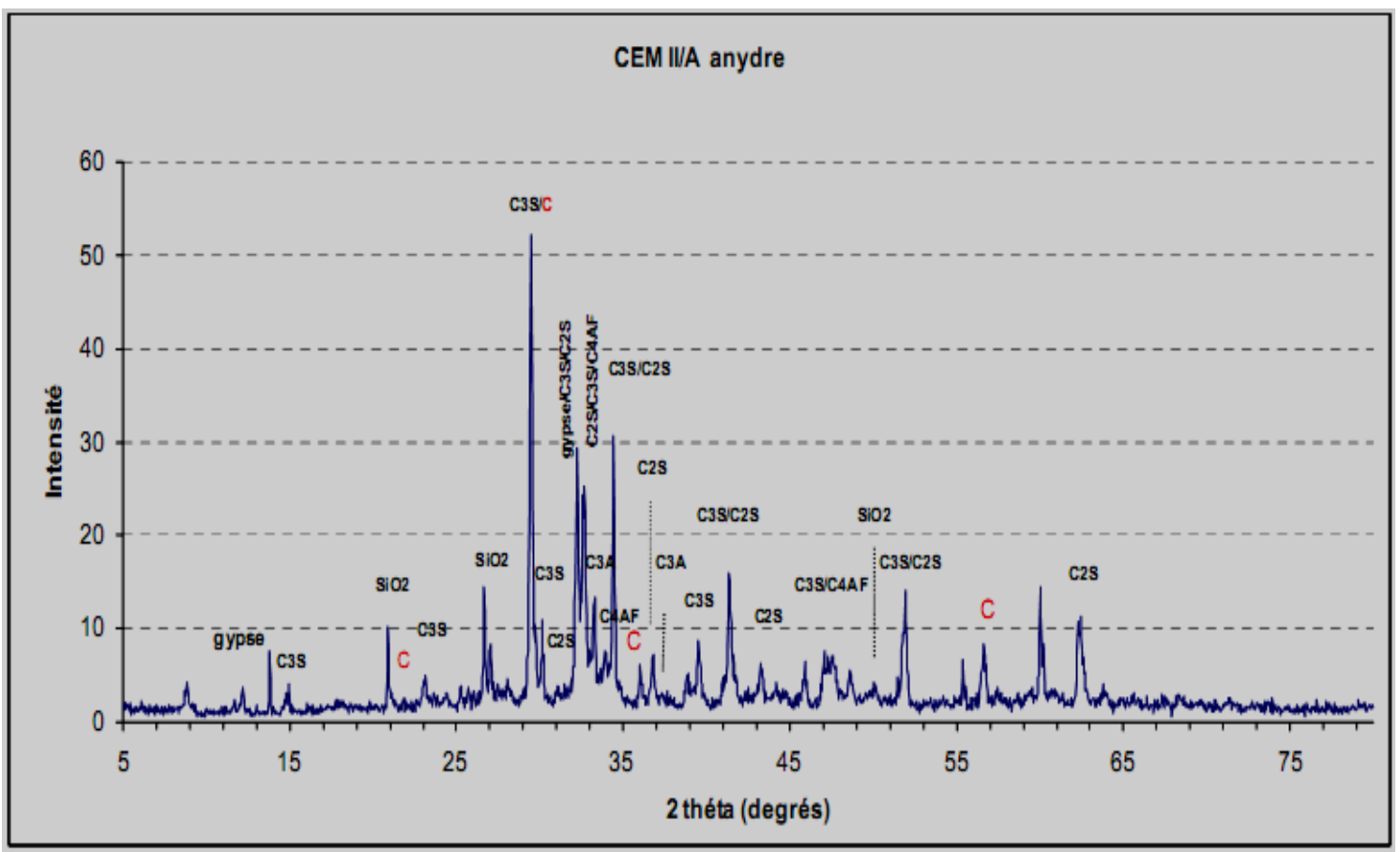

Figure 6. X-ray diffraction (XRD) analysis of cement CPJ CEM II/A 42, 5.

Table 3. Chemical analysis of the cement and the Bogue composition.

\begin{tabular}{|l|l|l|l|l|l|l|l|l|l|}
\hline $\mathrm{SiO}_{2}$ & $\mathrm{Al}_{2} \mathrm{O}_{3}$ & $\mathrm{Fe}_{2} \mathrm{O}_{3}$ & $\mathrm{CaO}$ & $\mathrm{MgO}$ & $\mathrm{SO}_{3}$ & $\mathrm{C}_{3} \mathrm{~S}$ & $\mathrm{C}_{2} \mathrm{~S}$ & $\mathrm{C}_{3} \mathrm{~A}$ & $\mathrm{C}_{4} \mathrm{AF}$ \\
\hline 21.25 & 5.32 & 2.41 & 54.19 & 1.52 & 1.89 & 65.70 & 16.85 & 5.42 & 12.03 \\
\hline
\end{tabular}

(iv) Mixing water - potable tap water was used for micro-concrete mixing all through the study and did not contain harmful impurities.

(v) Binary crushed gravel and crushed glass mixtures- the mixtures of large aggregates were carried out by substituting the calcareous gravel with waste glass at different ratesand presented in Table 4. By taking advantage of the essential natural property of the non-absorbent glass, the amount of mixing water was reduced which reduced the excess water in the micro-concrete composition which led to an improved compactness. 
Table 4. Coarse aggregatesmix ratio (Crushed gravel/Crushed glass).

\begin{tabular}{|c|c|c|}
\hline Mix designation & Crushed glass, (\%) & Crushed gravel, (\%) \\
\hline $\mathrm{M}_{0}$ & 0 & 100 \\
$\mathrm{M}_{5}$ & 5 & 95 \\
$\mathrm{M}_{10}$ & 10 & 90 \\
$\mathrm{M}_{15}$ & 15 & 85 \\
$\mathrm{M}_{20}$ & 20 & 80 \\
$\mathrm{M}_{25}$ & 25 & 75 \\
\hline
\end{tabular}

\section{Tests used}

The tests used to analyze properties of the micro-concrete in the fresh and hardened state were the following:

Slump test (Properties of fresh Concrete)- the slump test is a method to assess test the workability of fresh concrete. A standard metal slump cone (Abrams cone) was filled with four layers of fresh concrete, each layer was carefully compacted with a steel rod. The last layer that fills the cone upwards was Arrase trowel flat. The cone was then removed and the reduction of the height (subsidence) of the fresh concrete is measured. The slump test was used to evaluate the rheological behavior of fresh concrete mixture. The collapse was set between 4 and $6 \mathrm{~cm}$ for all blends of fresh concrete in this study. The workability is a property of fresh concrete and was measured by the slump test and is described as a consistency measure.

Mechanical tests- the specimens of the micro-concrete were subjected to mechanical compression tests. Mechanical strength was determined at 7,14 and 28 days on specimens of 10X10X10 cm prisms for different gravel mixtures. The water used in this study was drinking water. After moulding, the specimens were coated with plastic sheets at $20^{\circ} \mathrm{C}$ for $24 \mathrm{~h}$. After $24 \mathrm{~h}$, the test pieces were demoulded and stored in water tanks at $20^{\circ} \mathrm{Cuntiltested.} \mathrm{The} \mathrm{results} \mathrm{reported} \mathrm{in} \mathrm{this} \mathrm{article} \mathrm{are} \mathrm{the} \mathrm{mean} \mathrm{values}$ obtained. Table 5 shows the composition of the micro-concrete mixtures tested.C 0 is the corresponding control micro-concrete manufactured only with $100 \%$ limestone gravel (control sample, without replacement). C5, C10, C15, C20 and C25 are micro-concretes manufactured with binary aggregate containing calcareous crushed gravel and crushed glass. 
Table 5. Micro-concrete composition.

\begin{tabular}{|l|c|c|c|c|c|c|}
\hline Micro-concrete & $\begin{array}{l}\text { Crushed } \\
\text { glass } \\
(\%)\end{array}$ & $\begin{array}{l}\text { Crushed } \\
\text { glass (3/8) } \\
\left(\mathrm{kg} / \mathrm{m}^{3}\right)\end{array}$ & $\begin{array}{l}\text { Crushed } \\
\text { gravel(3/8) } \\
\left(\mathrm{kg} / \mathrm{m}^{3}\right)\end{array}$ & $\begin{array}{l}\text { Crushed } \\
\text { Sand(0/5) } \\
\left(\mathrm{kg} / \mathrm{m}^{3}\right)\end{array}$ & Cement & Mixed Water \\
$(\mathrm{kg})$ & $(\mathrm{l})$ \\
\hline C0 & 0 & 0 & 1010,69 & 669,88 & 393,12 & 210 \\
\hline C1 & 5 & 50,53 & 960,15 & 669,88 & 393,12 & 204,57 \\
\hline C2 & 10 & 101,70 & 909,62 & 669,88 & 393,12 & 200,82 \\
C3 & 15 & 151,60 & 859,10 & 669,88 & 393,12 & 199,13 \\
C4 & 20 & 202,14 & 808,55 & 660,88 & 393,12 & 194,70 \\
C5 & 25 & 252,67 & 758,10 & 669,88 & 393,12 & 190,64 \\
\hline
\end{tabular}

\section{RESULTS AND DISCUSSION}

\section{Fluidity}

The influence of the substitution of the crushed gravels of fraction $3 / 8$ by different contents of glass debris on the measured fluidity allowed to examine and analyze the reduction of the mixture water observed since the fluidity is maintained more or less constant. According to the results shown in Figure 7, the substitution of the crushed gravels of the fraction $3 / 8$ by the crushed glass results in a notable water reduction and it exceeded $9 \%$ for a substitution of $25 \%$ of crushed glass. This is mainly due to the nature of the glass (which does not absorb water) and the surface state of the glass debris which reduces the cohesive force between the grains which increases the fluidity of the micro-concrete mixtures. The obtained results in this study correlated well with previous research undertaken on the subject of reuse of glass (Mahmoud B.A et al., 2016; Shalini.singh, 2017). 


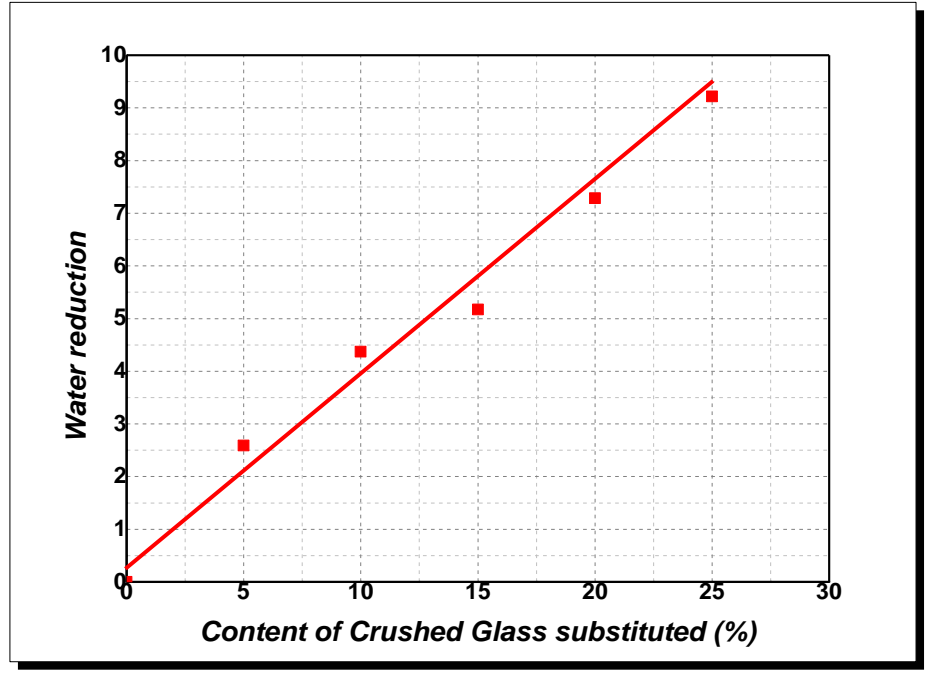

Figure 7. Water reduction as a function of the crushed glass content.

Effect of the substitution of crushed gravel by different rates of crushed glass on the water/cement ratio and water absorption

The substitution of crushed gravels of fraction 3/8 by glass debris of the same fraction allowed the reduction of the w/c ratio. By examining the results summarized in Figure 8, it can be seen that this water reduction increased as the percentage of substitution increased, this can be due to the reduced amount of crushed gravel present in the composition of the micro-concrete which limits the absorption of water and improves the rearrangement of the grains (fairly good fluidity) because the crushed glass exhibits a rather weak cohesion explained by their surface state (polished surface).

The substitution of crushed gravel (which absorbs water) by a percentage of glass debris ranging from 0 to $15 \%$ leads to a decrease in absorption because the surface state (polished) do not absorb water, but above $15 \%$ of substitution there is an increase in absorption this is mainly due to the increase in cohesion between grains due to the angular shape of the crushed glass which Produces an increase in the porosity of the micro-concrete (figure 9).

(Shalini.singh., 2017) noted that the percentages of the water absorption were reduced with rise in waste glass content. The lowermost value of the water absorption test was found for concrete mix with the $40 \%$ waste glass content.The obtained results regarding the water reduction in the present research work about the effect of waste glass aggregate replacement on water reduction are in a good agreement with previous studies (Mahmoud B.A et al., 2016; Shalini.singh., 2017). 


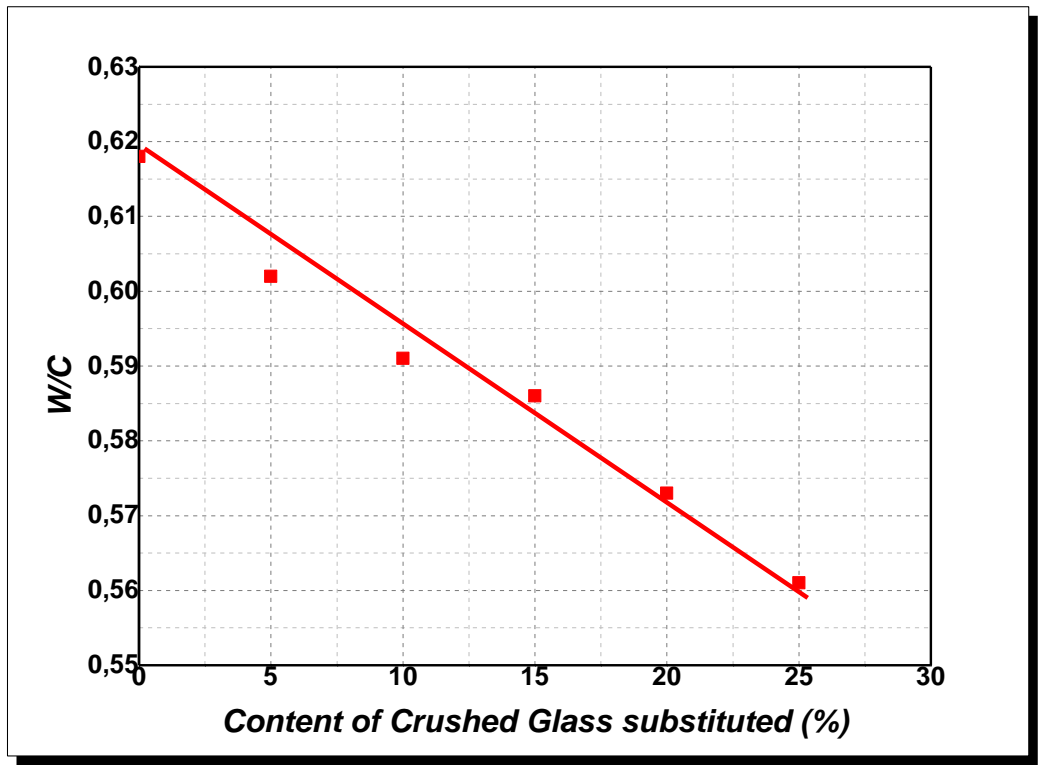

Figure 8. Water/cement as a function of crushed glass substitution percentage.

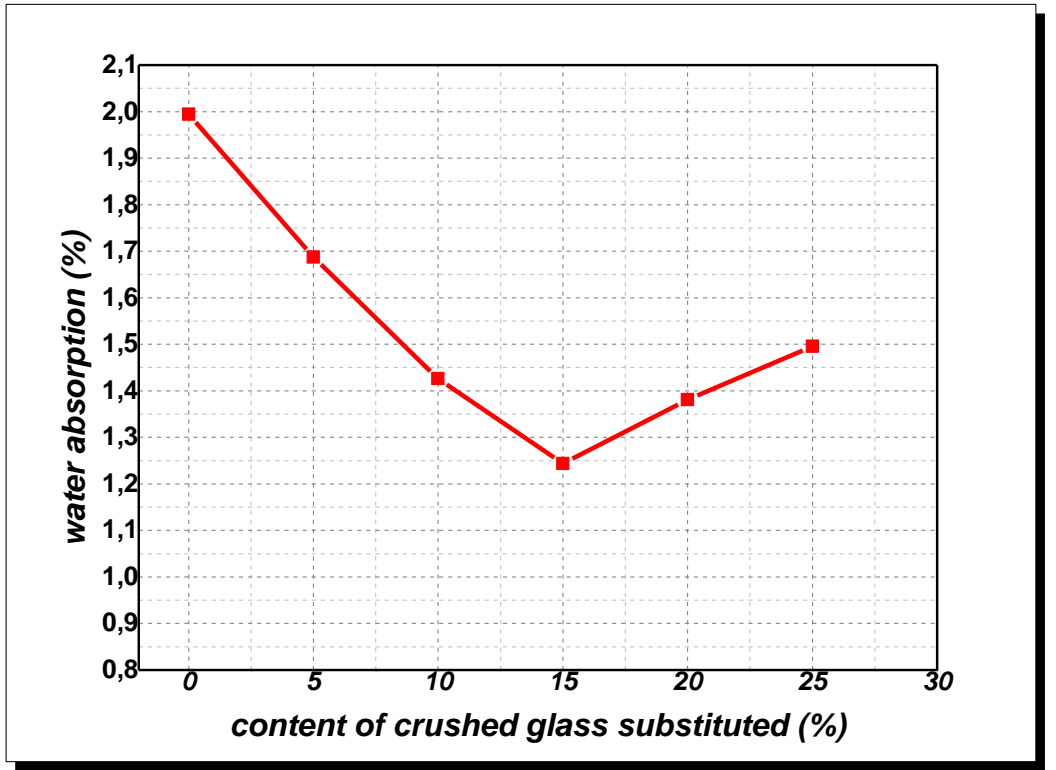

Figure 9. Water absorption as a function of crushed glass substitution percent. 


\section{Density}

In examining the results presented in Figures 10 and 11, the density was generally decreased when the substitution percentage of the crushed gravel by crushed glass increased. This is essentially due to:

(i) The density of crushed glass is less than the density of crushed gravel;

(ii) Despite the angular geometrical shape of the crushed glass which increases the cohesion between grains the surface state of the polished glass grains reduces this cohesion and maintains a fairly good degree of fluidity;

(iii) The decrease of the w/c ratio did not lead to an increase in the density of the micro-concrete because the reduction of this ratio was essentially due to the absence of absorbing aggregates (reduction of the percentage of the crushed gravel).

(Abdelmaseeh, B. K. et al., 2014) conclude that It is clear that, as expected, the density of concrete with WG decreases with increasing percentages of WG due to the difference between densityof WG and natural coarse aggregate. However, the decrease in density is not significant within the WG percentages used.

These are in accordance with results found in the present study, where a slight reduction is noticed with increased waste glass aggregate replacement up to the percentage of $25 \%$. The difference between density values is not significant ranging from 2250 to $2270 \mathrm{Kg} / \mathrm{m}^{3}$ at 28 days, respectively.

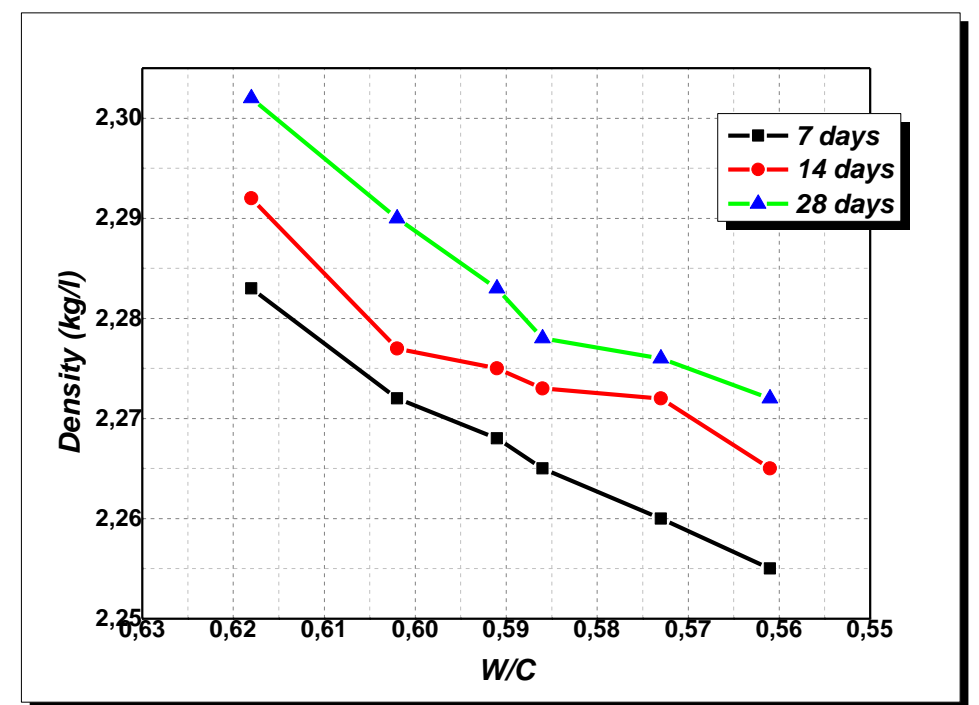

Figure 10. Density as a function of the water cement ratio (w/c). 


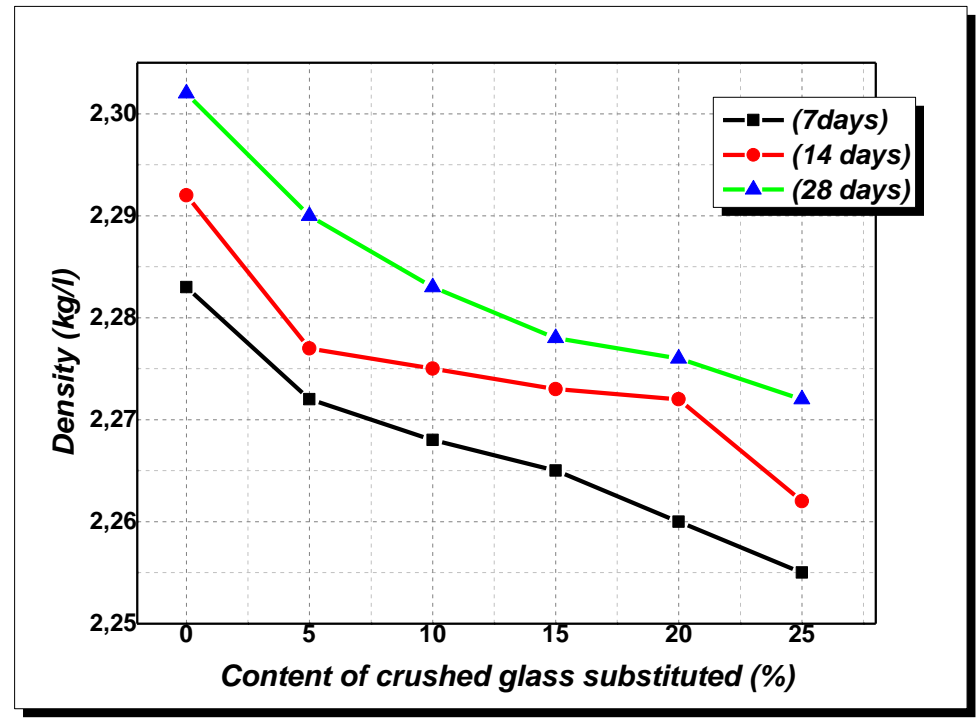

Figure 11. Density as a function of the crushed glass content.

\section{Mechanical strength}

The mechanical strength is expressed by the power of the concrete to resist destruction due to the stresses of the different compressive loads. The variation of the compressive strength was studied as a function of the w/c ratio and the percentage of crushed glass that makes up the micro-concrete matrix.

The results shown in Fig 12 suggest that the substitution of crushed gravel by any percentage of crushed glass did not influence the evolution (the behavior law) of the micro concrete over time.

The substitution of 0 to $10 \%$ of the crushed gravel by the glass aggregates of the same fraction gave rise to an increase in the compressive strength of the micro-concrete (Figures 13 and 14). Above $10 \%$ of substitution the compressive strength begins a continuous decrease, which is mainly due to the decrease of the adhesion cementaggregates paste, up to $25 \%$ substitution the compressive strength of the micro-concrete almost reached the resistance of the control micro-concrete, which is essentially due to the reduction of water by the presence of glass aggregates which are non-absorbent in nature.Then the cohesion between grains then remained large and created a porosity which makes the micro-concrete less resistant.

At $10 \%$ substituted glass debris the mixed water was reduced but the cement- 
aggregate paste adhesion kept at an appreciable value, which allowed to improve the compressive strength of the micro concrete by more than $27 \%$, with optimum strength reached a value of $46.33 \mathrm{MPa}$.

(Shalini.singh, 2017) noted that there is a decrease in compressive strength with increase in the percentage of the waste glass. There is a marginal increase in strength of concrete at $10 \%$ replacement.

A substitution of $25 \%$ of calcareous gravel by glass debris did not cause a decrease in resistance below the resistance of the control micro-concrete, and proportion of glass debris is recommended (Figure 13).

The optimum compressive strength of the micro-concrete was obtained at a w/c ratio equal to 0.59 that is a $15 \%$ substitution of the calcareous aggregates by glass waste (Figure 14). This is essentially due to reduction of the mixing water and a reduction in the cohesive forces between the grains.

(Seung Bum, P.et al.,2004) confirmed that the test results of fresh concrete show that both In addition the compressive, tensile and flexural strengths of concrete have been shown to decrease when the content of waste glass is increased. In conclusion, the results of this study indicate that emerald green waste glass when used below $30 \%$ in mixing concrete is practical along with usage of $10 \%$ SBR latex. In addition, the content of waste glasses below $30 \%$ is practical along with usage of a pertinent admixture that is necessary to obtain workability and air content.

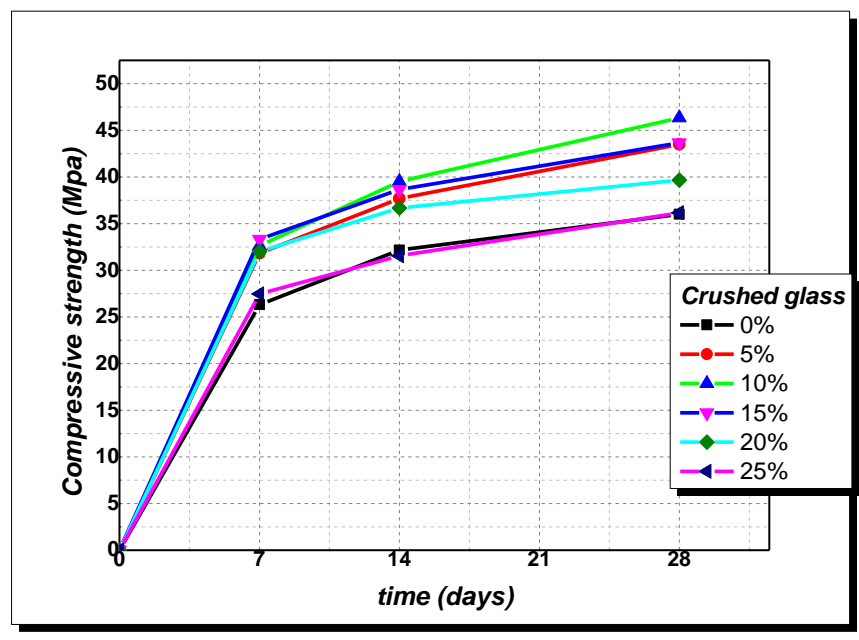

Figure 12. Compressive strength development over time with variable Crushed glass content. 


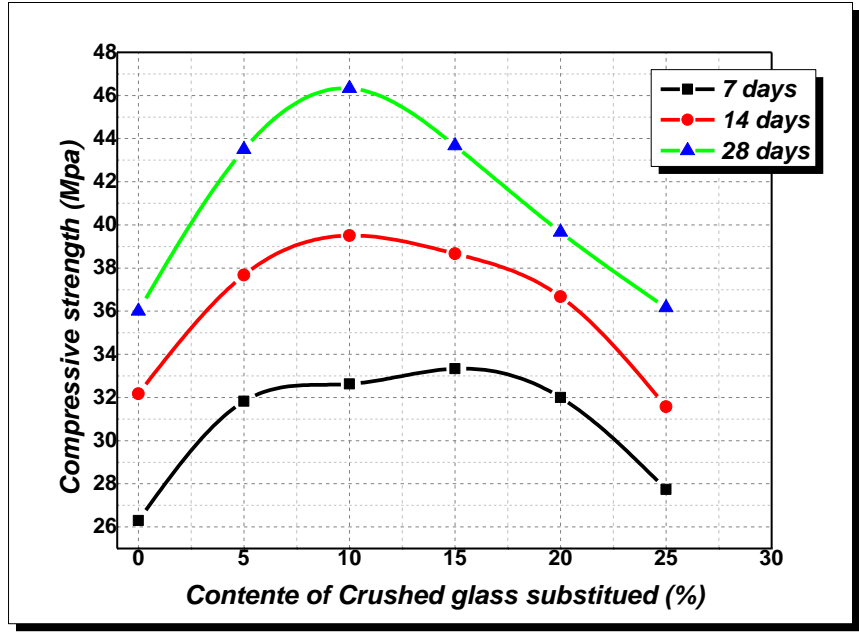

Figure 13. Compressive strength as a function of content of crushed glass substituted.

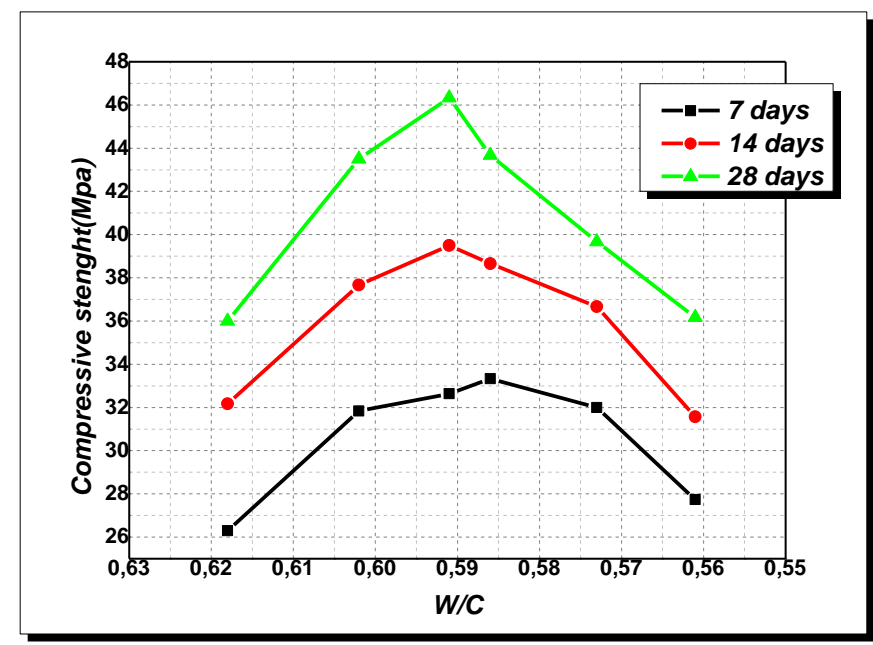

Figure 14. Compressive strength as a function of water-cement ratio (W/C).

Finally, we can conclude that the substitution effect of crushed aggregate of glass waste in concrete and micro-concrete are in agreement with the results found for researchers on the subject of reuse of waste glass aggregates replacement alike the experimental investigation done on micro-concrete here in (Seung BumP. et al.,2004; Serniabat T.S et al., 2016; Ravindra P. Et al, 2017). 


\section{CONCLUSION}

Based on the test results in the present investigation on the the incorporation of crushed glass in micro-concrete, the following conclusions could be drawn:

(i) The substitution rate of 5 to $25 \%$ of crushed gravel by crushed glass waste improves the physical and mechanical properties of the micro-concrete.

(ii) The low performance of behavior over time of the micro-concrete is less affected in regards of the substitution of crushed aggregate by crushed glass aggregate waste.

(iii) A reduction of mixing water demand around $10 \%$ was obtained for a substitution of $25 \%$ of limestone aggregates by crushed glass.

(iv) The compressive strength was considerably improved by substitution of crushed gravel by waste glass crushed aggregate at low rates. The optimum reached value of more than $46 \mathrm{MPa}$ was registered at $10 \%$ replacement of crushed limestone aggregates. This allowed a better strength performance improving by more than $27 \%$.

Finally, It could be concluded that the reuse of crushed glass waste to produce aggregates for the design of micro-concrete is beneficial at the technical, economic and environmental levels. This, by reducing the consumption of natural resources as well as landfills deposit in order to achieve a sustainable micro concrete formulation with similar performances to a conventional one based on natural crushed aggregates.

\section{ACKNOWLEDGEMENT}

The authors gratefully acknowledge technical support from the laboratory of the Civil Engineering Department, M'sila University, Algeria. Also, LAFARGE cement company of Hammam Dalaa, M'sila, Algeria for providing the cement used in the present research work.

\section{REFERENCES}

Abdelmaseeh, B. K. andGailan, J. Ibrahim. 2014. Effect of using windows waste Glass as coarse aggregate on some properties of concrete.Eng. \& Tech. Journal, Vol.32 (A6): 1519-1529.

Chen C.H., Huang R., Wu J.K., and Yang C.C. 2006. Waste E-glass particles used incement mixtures, Cement and Concrete Research, 36(3): 449-456.

Dragica J., Dimitrije Z., and Aleksandar S. 2012, Achieving Sustainability of Concrete by Recycling of Solid Waste Materials, Mechanical Testing and Diagnosis, 1: 22-39.

Girbes I., Suesta C., Lopez-Tendero M., and Belena, I. 2004, Recycled glass cullet as 
partial Portland cement replacement, International Conference of Sustainable Waste Management and Recycling, London, 14-15 September 2004, England: 141-148.

Gunalaan V., and Seri Ganis Kanapathy P. 2013, Performance of Using Waste Glass Powder In Concrete As Replacement Of Cement, American Journal of Engineering Research, 2(12): 175-181.

Jin, C., Meyer, C. and Baxter, S. 2000. Glass concrete : concrete with glass aggregate.ACI Materials Journal, 97: 208-213.

Liang, H., Zhu, H. and Byars, Ewan A. 2007.Use of waste glass as aggregate in concrete. Pp. In proceedings of the7th UK CARE Annual General Meeting, UK Chinese Association of Resources and Environment Greenwich.

Limbachiya, M., Meddah M.S. and Fotiadou, S. 2012. Performance of granulated foam glass concrete.Construction and Building Materials, 28(1): 759-768.

Liu, S.H., Xie, G.S. and Wang, S. 2015. Effect of curing temperature on hydration properties of waste glass powder in cement-based materials. Journal of Thermal Analysis and Calorimetry, 19(1): 47-55.

Liu, S.H., Xie, G.S. and Rao, M.J. 2013.Effect of waste glass powder on properties and microstructure of ultra-high performance cement based materials.Materials Research Innovations, 17(1): 210-214.

Liu, S., Wang, S., Zhou, W., LI, L., Xiao, H., Wei, J. and Tang, W. 2016. Strength and microstructure of mortar containing glass powder and/or glass aggregate. Journal of Wuhan University of Technology-Mater. Sci. Ed, 31(6): 1302-1310.

Mahmoud B.A. Alhasanat1, Arabi N. Al Qadi1, Salah Al-Thyabat2, Madhar Haddad3 \& Batool G. Nofal1. 2016. Addition of Waste Glass to Self-Compacted Concretell Modern Applied Science; Vol. 10, No. 11:1913-1852.

Ravindra PatilL, Payal Hon, Mrunmayee Sawai, MamtaSonawane, Shweta Khaire. 2017. Mechanical Properties Of Concrete Incorporating Recycled Aggregateand Glass Aggregate, International Journal of recent trends in Engineering and Research(IJRTER), Volume 03, Issue 01; January, 2455-1457.

Serniabat, T.S., Khan, M.N.N. and Zain, M.F.M. 2014. Use of waste glass as coarse aggregate in concrete: a Possibility towards sustainable building construction. International Journal of Civil, Environmental, Structural, Construction and Architectural Engineering, 8(10): 1075-1078.

Seung Bum, P., Bong Chun, L. and Jeong Hwan, K. 2004. Studies on mechanical properties of concrete containing waste glass aggregate. Cement and Concrete Research, 34(12): 2181-2189.

Shao, Y., Lefort, T., Moras, S. and Rodriguez, D. 2000.Studies on concrete containing ground waste glass.Cement and Concrete Research, 30: 91-100.

Shalini. Singh., 2017. Partial replacement of coarse aggregate with waste glass in concrete.International Journal of Innovative Research in Science, Engineering and Technology, Vol. 6(4). 
Shayan,A. and $\mathrm{Xu}, \mathrm{A} .2004$. Value-added utilization of waste glass in concrete.Cement and Concrete Research, 34(1): 81-89.

Topcu, I.B.and Canbaz, M. 2004.Properties of concrete containing waste glass.Cement and Concrete Research, 34(2): 267-274.

Zhang, M.J.and Zhao, H. 2011.A Study on the waste glass recycled as buildingmaterials.Journal of Jingling Institute of Technology, 27(2): 51-56. 